\title{
Conceptualizations of Nature in Classical Indian Philosophy Ecological Issues*
}

\author{
Elena Anikeeva \\ Department of History of Philosophy \\ Peoples' Friendship University of Russia (RUDN University) \\ 6 Miklukho-Maklaya Street \\ Moscow, Russian Federation 117198 \\ E-mail: hotkovskaya7@gmail.com
}

\begin{abstract}
The following article deals with the varieties of interpretations and conceptualizations of nature in classical (ancient and medieval) Indian Philosophy. We find in these conceptualizations the fruitful ideas for environmental philosophy. Cosmos and the nature are nearer to impersonal principle than to personality. Many scholars assert that conceptualizations of nature in Indian religious and philosophical outlook are included in pantheistic (or panentheistic) framework. In addition, theism (nonmonotheistic theory about Personal God/gods as attribute(s) or subordinate(s) of impersonal principle - Brahman, Nirvana etc.) is not alien to Indian thought and brings serious ecological issues. Pantheistic doctrines in Indian philosophy explicate the idea of unity of the whole universe, people and nature. Indian theistic tradition (ishvara-vada) teaches us, human beings, to expand our responsibility, trusteeship and care of the nature.
\end{abstract}

Keywords-conceptualization of nature; pantheism, panentheism; Theism; Indian Theism (ishvara-vada); classical Indian philosophy; environmental philosophy

\section{INTRODUCTION}

Nature in Indian Philosophy has varieties of interpretations, concepts and conceptualizations. We try to trace in these conceptualizations possible fruitful ecological issues about the relationship between people and nature, and the human's awareness and response for the destiny of the universe. In ancient and medieval times, people knew neither about ecological crisis nor about its causes. In our days, humankind is deeply concerned with solving of the crying global problems such as destruction of nature, pollution our environment. Therefore, we need not only to work harder for solving global problems but also to examine our contemporary outlook by enriching it with revitalization of traditions. A. Brennan and Y. S. Lo stress the actuality of the problem regarding that "contemporary environmental crisis suggests that some of our underlying cultural, religious and political beliefs and attitudes are responsible for our behaving badly towards the environment. In other words, our religious worldviews, our basic political and social ideas, are not environmentally innocent" [1].

*The publication was prepared with the support of the "RUDN University Program 5-100".
Meera Baindur has summarized and analyzed general views on nature in classical Indian philosophy as well as contemporary discussion of linked ecological and environmental problems: "the resources for environmental ethics in Indian philosophy will have to be drawn from a set of pre-modern traditions that are to be found in a context that is historically earlier to the awareness of an environmental crisis" [2]. Although I highly estimate her profound investigation of these questions, my attitude differs from that of Meera on topical and methodological levels. She deals with naturalistic and ethical aspects of Indian philosophy predominantly; I consider metaphysical and ontological aspects precisely and draw positive ecological issues not only out of pantheistic/panentheistic outlook but also out of theistic tradition.

\section{RELIGIOUS FRAMEWORK}

We cannot understand the conceptions of nature in ancient and medieval Indian Philosophy without their coherence with religious outlook. Moreover, every philosophical school in India excluding Lokayata depends on or includes in one of the three traditional endemic Indian religions: Hinduism, Buddhism, and Jainism. It is not a sort of religious violence upon philosophy but a matter of fact that almost all Indian thought is rooted in religious systems. As far as no one of Indian religions is monotheistic, and in monotheistic paradigm, there is one personal God, the Indian religions belong to polytheistic paradigm. When we see in this paradigm many personal gods, we conclude that something may unite these personal gods and that something must be stronger and broader than those personal gods - we find some impersonal Principle, Divine/World Spirit, force or law, Cosmos, and so on. Yes, there is Brahman in neutral gender, nirvana without any substantial character, impersonal moksha as soteriological ideals that occupy the top place in Indian traditional religions; meanwhile personal gods are allowed to take lower levels in ontological hierarchy. That means that pantheism or panentheism has become a usual framework of Indian philosophy. Cosmos and the nature in fact are nearer to impersonal principle than to personality. Therefore, many scholars assert that conceptualizations of nature in Indian philosophical outlook are pantheistic (or panentheistic) [3]. I agree with this tenet. 
Pantheistic outlook means that all that exists: nature, people, other living creatures, - is Divine or is a part of impersonal Deity. However, theism is not alien to Indian thought. Indian thinkers conceive the Deity or soteriological ideal both impersonal and personal with dominating of impersonal Absolute; and Indian schools of metaphysics combine two trends in different proportions, sometimes harmonizing them, sometimes making them combat with each other. Therefore, I use 'theism' in a broader sense than 'monotheism' because there is a sharp difference between Theism in Abraham religions and theistic tendencies in polytheistic paradigm [4]. Indian theism means nonmonotheistic theory about Personal God/gods as attribute(s), emanations or subordinate(s) of impersonal principle Brahman, Nirvana etc. We explain this by following.

In Vedic religion, gods act through nature and the Deities themselves are nothing but personalization of nature. That means, natural elements and Deities/Devasare in interchange and interpenetration: gods become natural forces and vice versa [5]. The number of Rig-Vedic gods accounts up to 3 thousand but there was no strict hierarchy of Deities in Vedas: some god might become chief when people worshiped it (phenomenon of henotheism). However, main master over all gods was impersonal Rita, which is cosmic, moral and social order penetrating the spiritual and physical universe. Rita symbolizes unalterable force of destiny and like Cosmos in Pythagorean philosophy structures the universe with its proportions, laws and harmony in opposition to nirrita/acosmia that is destructive forces, disorder, chaos. In sum in Vedic mythology, we see the pantheistic essential unity and unanimity between divine and mundane, gods and nature.

Upanishads develop Vedic worldviews and demonstrate similar attitude to the nature. The question of ontological relation between natural and divine reality is solved in Upanishads in two ways. 1) Main tendency asserting impersonal Atman-Brahman as universal substance, order and soteriological ideal; 2) in addition to it theistic concept of personal Lord (Ishvara/Maheshvara, or another God's name) who initiates the development of cosmos and the nature, sustains and destroys them within the cyclic process. Scholars insist that these two tendencies, personal and impersonal, e.g. panentheistic and theistic are not in contradistinction in Upanishads but they are supplementary to each other. Aurobindo Ghosh says, "Unknowable manifests itself in double aspects of Personality and Impersonality" [6].

These two tendencies may combine due to AtmanBrahman, which is both material and creative cause of the universe. Impersonal apophatic Atman-Brahman manifests into cataphatic personal God through emanation, and its next stage is evolving cosmos with all its components out of Divine essence. Panentheistic conceptualization of nature in Upanishads is expressed by the words, "Thou who is One, in whom the universe is embedded... That is truly fire, sun, That is wind, moon; That is pure, That is Brahman, water..." [7]
Theistic doctrine of Indian philosophy has its origin in Upanishads. The term for theism elaborated in Indian tradition is ishvara-vada, or teaching about Ishvara (Lord). Theistic conceptualization of nature in Upanishads makes accent on Maheshvara ('Great Ishvara') who is prior to the whole universe, rules it and gives powers to all in it. Upanishads say that neither time (kala), nor intrinsic nature of every being (svabhava), nor necessity (niyati), nor natural elements (bhutas), are fundamentals themselves. Only Lord Ishvara sustains the combination of mortal and immortal, of revealed and unrevealed [8]. In theistic concept new approach to the nature has appeared. Reason and care of a Person are in need for the cosmos to keep and sustain it in a proper way. This theistic concept of Upanishads developed further in Indian philosophy by ishvara-vada.

Cross-religious archetype of karma-samsara appeared in Upanishads, pierced overwhelming majority of endemic Indian doctrines and became dominant in explaining the causes of bondage. This archetype constitutes the basis of Indian conceptualization of nature and it has pantheistic character. At first, the law of karma though called 'eternal moral order' operates in a way of natural determinism. From one hand, only a creature, which possesses consciousness, response and moral motive, creates the karmic picture, its "fruits" (phala). From the other hand, these "fruits" of karma are not in any case alterable, so, inalterability of all karmic effects if not immediate then long lasting shows the necessity, inevitability and rigid framework of afterlife`s retribution.

At second, samsara, i.e. reincarnation or rebirth process fully depends on karmic law. As far as a personality cannot bear more than one body and cannot forget his/her selfawareness a personality like a substance is lost in cross-lives and cross-bodies migration. What reborn is not 'who', but 'what' - only karmic substrate. In result, the doctrine of samsara has pantheistic background. Not only because of all physical and biological processes are included in karmicsamsaric cycles, but due to submission of conscious and moral action to that physical cycles I call the law of karma samsara 'moral-and-natural determinism' [9].

Pantheism shaped the key conceptualizations of nature in Indian religions; however, theistic trend in them was important also.

\section{INDIAN PHILOSOPHIES ON NATURE; ECOLOGICAL ISSUES}

Pantheistic and panentheistic framework of Indian religion had stimulated the development of basic impersonal categories marking the nature in Indian philosophies: bhutas (natural elements) - in Lokayata; svabhava ("own being", or intrinsic nature of everything) - in svabhava-vada and Lokayata; Prakriti ("primordial matter") - in Samkhya; paramanu ("the smallest thing", or atom) - in NyayaVaisheshika, Mimamsa; and some others.

Lokayata is a school of total materialism due to negation of any supernatural and spiritual substance, God and even negation of karma-samsara with its moral motive. What exists is only natural elements - bhutas (like fire, air, water, earth) and their modifications in different forms including 
human`s consciousness. In addition to hedonism and atheistic critique of religion and cults Lokayata`s materialism provoked unrespectable image and ostracism against itself. Notwithstanding Lokayata`s eulogizing the nature its issue for environmental philosophy is minimum. If conscious, spiritual and moral powers in the universe are negated therefore all the processes in physical and social world, also the crises might be considered as some 'natural necessity', i.e. they might be inevitable and fatal. Then the responsibility of human being is losing. This limitation of materialism can lead to moral relativism and nihilism.

In Jain philosophy, the nature is represented by two categories - jiva (anima; what is alive) and pudgala (matter; what is not alive). These two substances are not in mechanical interrelations: jiva seeks salvation and salvation means deprivation from pudgala's bondage, which is a sort of karmic sticky liquor catching jiva due to its sins. All the nature is animated according to Jains because of majority of jivas penetrating pudgala and they may be visible as well as invisible out of their bondage. Conceptualization of nature in Jain philosophy has a character of soteriological ontology around perished and perishing jivas. Jain philosophy shares general pantheistic background in Indian conceptualizations of nature in interrelations between jiva and pudgala: jiva becomes extensible and "material". Meanwhile Jain peculiarity consists in tender and adorable attitude to every creation in the universe either alive or not alive due to downtrodden jivas inside it.

Environmental and ecoethical issues from Jain philosophy are grand because of soteriological conceptualization of nature/jiva. Jain ethics looks like some ecological canon prohibiting any harm or violence against nature/jiva and promoting non-violent (ahimsa) way of life. One knows that Jains, for example, set hospitals for rats; Jains abstain murder of mosquitoes, worms, and so on. That is why not only hunting but agriculture also as a job was restricted in Jain community. We do not want to say that all people have to pursue Jain ethics, but the necessity of a new ecoethics fulfilled with respect, awe and tenderness towards the nature like Jain's is evident in face of global crisis. As for subjective ecological issues from Jain philosophy is concerned, we can stress its severe asceticism. The Jain monk practiced the most rigorous forms of asceticism and the Jain laity transformed asceticism into activity within the world - good works toiling ceaselessly. No system of Indian philosophy placed so much importance on good works. It is a good lesson for contemporary men and women with so many surplus demands and desires (and for leisure-bones also).

Samkhya in classical period is a philosophy of dualism in which there are: transcendental spirit Purusha and immanent primordial matter Prakrity; the former as a passive spectator stimulates evolution and involution of the latter with all its natural bhutas and all mental properties of conscious subjects. Samkhya shares pantheistic conceptualization of nature of other Indian schools; impersonal intellect (buddhi), impersonal self-consciousness (ahamkara), then individual senses (indriya) and individual mind (manas) are by stadia evolved inside Prakriti, final products of which are brute material bhutas. Considering original and active Prakriti with all its products apart from Purusha we have to call the conceptualization of nature in Samkhya more materialistic than pantheistic [10].Ecological issues from conceiving nature in Samkhya have the same pretensions and limitations, which a materialistic system has.

The most theistic schools in Indian philosophy are amalgamated Nyaya-Vaisheshika (NV). Borrowing theistic ideas and some arguments from Upanishads and early Yoga system Nyaya-Vaisheshika had become a flagman of ishvara-vada and synthesis of theistic trends in Indian philosophy looking like a rich flourishing many branched (mean, many texts) tree. Conceptualization of nature in NV is founded on theism and at the same time bears features of pantheistic outlook, but theistic content is overwhelming. Key ideas traced throughout the whole history of the system have concentrated around two items: 1) attributes of Ishvara, 2) reasoning and argumentations in favor of God`s existing [11].

Theistic attitude to the nature supposes the existing of supernatural benevolent Person who is if not Creator of the universe ex nihilo then the Organizer or Demiurge of passive matter or elements into the proportional, harmonic, intelligent and "the best of possible worlds" (Leibnitz). In addition, personal God does not leave its creature after organizing it but keeps, cares and leads it to better results due to his love. All these characteristics of the Lord/Ishvara and his attitude to the nature found in NV. Argumentation in favor of God's existence in NV was elaborated intensively, accurate and in a subtle way, so NV's philosophical discourse was more impressive than Western medieval scholasticism. Udayana, the Nyaya 'master' (acharya) of X century in his brilliant «Nyaya-kusumanjaly» («The Handful of Blossoms of Nyaya») criticizing in detail his opponents nirishvara-vadins (anti-theists) asserts that the nature itself cannot exist without Ishvara's supporting effort and guarding. "The world depends upon some being who possesses a volition which hinders it from falling, because it has the nature of being supported, ...the world can be destroyed, because it is destructible, like cloth which is rent" [12]. In other words, nature itself is nothing but 'entropic' system gradually coming to its death/dissolution. Pantheistic aspect of NV consists in conceiving atoms (paramanu) as primordial natural elements, which are eternal, not created, and may be combined and organized by Ishvara's will; atoms had been rethought in late NV as Ishvara's own body.

The fruitful ecological issue of NV derives from its theodicy: God, because He is God, always and eternally might not in any case be deprived of his benevolence; and the origin of evil totally depends on conscious creatures and spreads by the law of karma. All that is good comes exclusively from Lord; all that is bad comes exclusively from human being. Therefore, humankind must be aware of its responsibility for everything that is not in harmony, not coherent to God's beautiful plan of the universe, that misbalance with moral law etc. Theism of the system teaches us not only to be responsible for our actions, deals and their incomes, but also to prevent evil in face of perfect Lord. 


\section{CONCLUSION}

Conceptualizations of nature in classical Indian philosophy, especially Jainism and Nyaya-Vaisheshika have many serious and profound ideas that can nourish ecological thinking. In opposition or may be in addition to Meera Baindur I consider not only pantheistic but theistic Indian issues too for environmental philosophy. Pantheistic Indian doctrines explicate the idea of unity of the whole universe, people and nature. Indian theistic tradition (ishvara-vada) teaches human beings to expand our responsibility, trusteeship and care of the nature.

\section{REFERENCES}

[1] A. Brennan \&Y. S. Lo. Understanding environmental philosophy. Durham: Acumen, 2010, p. 7.

[2] Meera Baindur. Nature in Indian Philosophy and Cultural Traditions (Series: Sophia Studies in Cross-cultural Philosophy of Traditions and Cultures. Volume 12). Springer (India) Pvt. Ltd., 2015. Xv, 219 p. DOI 10.1007/978-81-322-2358-0, p. 46.

[3] Ibid., pp. 51; 63.

[4] Elena N. Anikeeva. Problems of Indian Theism: Philosophical and Comparative Analysis. - Moscow: Orthodox St. Tikhon's Humanitarian University Publisher, 2013, 256 p. (in Russian).

[5] See: Gonda J. Some observations on the relations of the «gods» and «powers» in the Veda. Gravenhage, 1957. 258 p.

[6] Aurobindo Sri. The Upanishads: Texts, translations and comments. P. 1. - 2nd ed. Pondicherry: Sri Aurobindo Ashram, 1981, p. 51; also pp. $19 ; 52$.

[7] Shvetashvatara Upanishad. IV. 1-2.

[8] Shvetashvatara Upanishad. I.2; I.8.

[9] In detail see: Elena N. Anikeeva. Fundamentals of Indian Religiosity: Dialectics of Personal - Impersonal. Moscow: RUDN University, 2010 (in Russian).

[10] N. P. Anikeev. Materialism and atheism of Samkhya system of early medieval period: $\mathrm{PhD}$ Thesis. Institute of Philosophy, USSR Academy of Sciences, Moscow, 1957 (in Russian).

[11] Bulcke Camille. The Theism of Nyaya-vaisesika, its Origin \& Early Development. Delhi - Varanasi - Patna: Motilal Banarsidass, 1968, p. 7.

[12] The Nyayakusumanjali of Udayanacharya with Translation and Exposition by N.S. Dravid. Vol. I. N. Delhi, Munshiram, 1996, pp. 369-375. 